\title{
Synthesis of Long, Representative DNA Copies of the Murine RNA Tumor Virus Genome
}

\author{
ELLEN ROTHENBERG AND DAVID BALTIMORE* \\ Center for Cancer Research, Massachusetts Institute of Technology, Cambridge, Massachusetts 02139
}

Received for publication 23 July 1975

\begin{abstract}
Virions of Moloney murine leukemia virus can synthesize two classes of DNA molecules complementary to their $70 S$ RNA. One class consists of molecules about 200 nucleotides long, which are of limited sequence complexity; these molecules are formed preferentially if the dNTP concentration during the reaction is low. The second class consists of very heterogeneous DNA molecules with weight-average size of about 1,000 nucleotides containing at least $70 \%$ of the viral RNA sequences in approximately equal concentration. The longest of these molecules can be 5,000 nucleotides long. This second class of DNA is formed in large amounts only in reactions containing dNTP concentrations of $0.2 \mathrm{mM}$ or higher. In such reactions after $24 \mathrm{~h}$ of incubation, at least $35 \%$ of the input RNA is represented in DNA copies. The ability to make long, representative DNA transcripts of tumor virus RNA provides a source of excellent probes for molecular hybridization.
\end{abstract}

The discovery of reverse transcriptase $(1,15)$ offered the possibility of using in vitro analysis to study the replication of $\mathrm{C}$-type viral genomes in molecular detail. Attempts to study DNA provirus formation in vitro, however, have encountered serious obstacles; poor efficiency of transcription, small DNA products, and unequal representation of the viral RNA sequences in the DNA product have been common findings (for references, see 14). The poor quality of the DNA products has led to suggestions that cellular factors, such as ligases and "unwinding proteins," might be necessary to allow the viral polymerase to copy the viral genome into a continuous molecule of DNA (11).

Recently, reverse transcriptase isolated from avian myeloblastosis virus was shown to be capable of making full copies of purified mRNA's 650 or more nucleotides long if the substrate dNTP levels were sufficiently high (5, 10; S. Drost and D. Baltimore, unpublished data). Enhancement of the rate of reverse transcription at high substrate concentrations has also been reported (8-10). To apply these findings to the study of viral genome copying, we have examined the effect of high dNTP concentrations on the endogenous reverse transcription carried out by detergent-disrupted virions of Moloney murine leukemia virus (MMuLV). In the present communication, we report a dramatic increase in product size as well as a high efficiency of template utilization in the presence of substrate concentrations of $0.2 \mathrm{mM}$ and higher.

\section{MATERIALS AND METHODS}

Purification of virus and viral RNA. The virus used in these experiments was clone $1 \mathrm{M}-\mathrm{MuLV}$, described by Fan and Paskind (7). Virus was harvested from roller bottles of NIH/3T3 cells producing the virus (CL-1 cells) and purified as described previously (6), except that TNE buffer $(0.1 \mathrm{M} \mathrm{NaCl}$, $0.05 \mathrm{M}$ Tris-hydrochloride ( $\mathrm{pH} 7.5), 0.001 \mathrm{M}$ EDTA) was substituted for $0.01 \mathrm{M}$ Tris ( $\mathrm{pH} 7.5$ ) for isopycnic banding of virions and resuspending the virus pellets. "Rapid-harvest" virus was kindly provided by U. Olshevsky. This had been harvested at 2 -h intervals, clarified immediately, and kept unfrozen at $-7 \mathrm{C}$ prior to processing. Pellets of banded virus were suspended in sterile $0.01 \mathrm{M}$ Tris-hydrochloride $(\mathrm{pH}$ 7.5) at a concentration of 5 to $10 \mathrm{mg}$ of protein per $\mathrm{ml}$.

Unlabeled 70S RNA was extracted from 10 to $15 \mathrm{mg}$ of M-MuLV protein as described previously (7). The deproteinized RNA was purified further by a second sodium dodecyl sulfate (SDS)-sucrose gradient centrifugation, recovered by ethanol precipitation, dissolved in $10 \mathrm{mM}$ EDTA, and quantitated, by absorbancy readings at $260 \mathrm{~nm}$, in a Beckman model 25 spectrophotometer. ${ }^{32} \mathrm{P}$-labeled $70 S$ RNA was prepared in a similar fashion. To label the virus, confluent growing CL-1 cells in roller bottles were washed twice in phosphate-free medium and incubated for $4 \mathrm{~h}$ in phosphate-free medium with dialyzed calf serum. ${ }^{32}$ P-labeled $\mathrm{P}_{1}$ (New England Nuclear Corp.; $20 \mathrm{mCi}$ per roller bottle) in fresh phosphate-free medium was added, and the cells were allowed to take up the label for $12 \mathrm{~h}$. The labeling medium was discarded, and at 
3-h intervals virus was harvested in complete medium and processed as for rapid harvest virus. After isopycnic banding, the pellet of virus was lysed in $2 \%$ SDS, and $70 S$ RNA was purified as described above, with the omission of the second SDS-sucrose gradient centrifugation. The specific activity of the viral RNA was $0.7 \times 10^{6}$ counts $/ \mathrm{min}$ per $\mu \mathrm{g}$.

Endogenous reverse-transcriptase reaction. All reactions were carried out in the presence of 40 to 100 $\mu \mathrm{g}$ of actinomycin D (a kind gift of Merck, Sharp and Dohme) per $\mathrm{ml}$. The standard reaction mixture contained $50 \mathrm{mM}$ Tris-hydrochloride ( $\mathrm{pH} 8.3) 10$ to 20 $\mathrm{mM}$ dithiothreitol, $60 \mathrm{mM} \mathrm{NaCl}$, and $0.01 \%$ Nonidet P-40 (Shell). Three dNTP's were present at $5 \mathrm{mM}$ each, and the fourth was added at the concentrations indicated in the text and figure legends. The concentration of magnesium acetate in the reaction was adjusted to be about 1.5 times the total concentration of dNTP in the reaction mixture. Virus was always added last, to a final concentration of up to $3 \mathrm{mg}$ of viral protein per $\mathrm{ml}$. To incorporate a conveniently large amount of radioactivity, it was necessary to lyophilize [ $\left.{ }^{3} \mathrm{H}\right] \mathrm{dGTP}$ or $\left[{ }^{3} \mathrm{H}\right] \mathrm{dCTP}$ (New England Nuclear Corp.) in the reaction tube and to redissolve it in the reaction mixture. Recovery was always monitored, and in plastic tubes losses were less than $10 \%$. Thus, $3 \mathrm{mCi}$ of $\left[{ }^{3} \mathrm{H}\right] \mathrm{dCTP}$ concentrated into a reaction volume of $1 \mathrm{ml}$, with $5 \mathrm{mM} \mathrm{dCTP}$, yielded a product with a specific activity of 100 counts/min per pmol of nucleotide incorporated (counting efficiency, $33 \%$ ).

Solutions were autoclaved if possible, and sterile glassware and plasticware were used. Unlabeled dNTP solutions were treated with Chelex 100 resin to remove heavy-metal ions, filtered through sterile membrane filters (Millipore Corp.), and then quantitated by absorbance at $\lambda_{\max }$.

Incubation at $37 \mathrm{C}$ was terminated by diluting the sample into 1 to $2 \mathrm{ml}$ of a solution containing $0.2 \mathrm{M}$

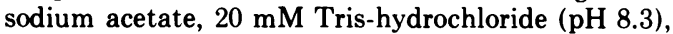
$50 \mathrm{mM}$ EDTA, and $0.5 \%$ SDS. Carrier yeast RNA was added to $70 \mu \mathrm{g} / \mathrm{ml}$, and the reaction mixture was extracted twice with redistilled phenol saturated with $0.5 \mathrm{M}$ Tris-hydrochloride ( $\mathrm{pH}$ 8.5)-0.2 M sodium acetate. The phenol phases were pooled and extracted with $0.2 \mathrm{M}$ sodium acetate- $20 \mathrm{mM}$ Tris $(\mathrm{pH} 8.3)$. The aqueous phases were then pooled, extracted with $\mathrm{CHCl}_{3}$ containing $4 \%$ isoamyl alcohol, and transferred to polyallomer SW41 rotor tubes with 2.5 volumes of absolute ethanol. The precipitate was recovered and dissolved in 0.02 $\mathrm{M}$ Tris ( $\mathrm{pH} \mathrm{8.3)-0.002} \mathrm{M} \mathrm{EDTA.}$ Recovery of DNA was typically 70 to $90 \%$. The DNA and RNA were freed from unincorporated nucleoside triphosphates by chromatography through Sephadex G-50, collected in sterile plastic tubes, and either stored at $4 \mathrm{C}$ or precipitated again with ethanol. Under these conditions, denatured, EcoRI-cleaved simian virus 40 (SV40) DNA survived incubation with virus for $4 \mathrm{~h}$, followed by full purification, with less than one nick per molecule; undenatured DNA, incubated for $2 \mathrm{~h}$, was virtually undegraded.

Alkaline sucrose gradients. Samples for alkaline sucrose gradient analysis were ethanol precipitated, dissolved in $0.2 \mathrm{ml}$ of $0.3 \mathrm{M} \mathrm{NaOH}-0.7 \mathrm{M} \mathrm{NaCl}-0.005$
M EDTA, and layered onto $11.0-\mathrm{ml}$ gradients of 15 to $30 \%$ sucrose in the same buffer with $0.1 \%$ Sarkosyl. Gradients were centrifuged in an SW41 rotor at 40,000 rpm for $16 \mathrm{~h}$ at $22 \mathrm{C}$. Fractions of $0.36 \mathrm{ml}$ were collected by puncturing the bottom of the tube; for direct counting, they were neutralized, diluted to 1.9 $\mathrm{ml}$, and counted in $10 \mathrm{ml}$ of Handifluor (Mallinckrodt). In preparative gradients, fractions were neutralized with $0.5 \mathrm{ml}$ of $0.1 \mathrm{M}$ Tris- $0.2 \mathrm{M} \mathrm{CH}_{3} \mathrm{COOH}$. After aliquots were counted; the fractions of interest were pooled with 35 to $40 \mu \mathrm{g}$ of yeast RNA per $\mathrm{ml}$ and 2 volumes of absolute ethanol.

The size marker for the alkaline sucrose gradients was SV40 DNA labeled with [methyl $-{ }^{14} \mathrm{C}$ ] thymidine, isolated as supercoils by ethidium bromide-cesium chloride banding, and cleaved with EcoRI restriction endonuclease (12), kindly provided by S. Rozenblatt. Molecular weights were calculated from sedimentation coefficients, relative to the $16 S$ SV40 linear DNA, by the method of Studier (13).

Nucleic acid hybridization. DNA and RNA samples for hybridization were mixed in plastic Brinkmann micro-test tubes with SDS present to facilitate transfer. Concentrated $\mathrm{LiCl}$ was added last, and duplicate 4- to $7-\mu 1$ volumes of the mixture were sealed in $50-\mu$ l Drummond microcaps. The reactions were carried out in 10 to $20 \mathrm{mM}$ EDTA- $0.2 \%$ SDS- 0.9 $\mathrm{M} \mathrm{LiCl}$ at $67 \mathrm{C}$. Equivalent $\mathrm{C}_{0} \mathrm{t}$ or $\mathrm{C}_{\mathrm{r}} \mathrm{t}$ values for 0.18 $\mathrm{M} \mathrm{Na}^{+}$were calculated by the method of Britten and Smith (3). The resulting hybrids were analyzed by determining the amount of acid-precipitable radioactivity after digestion with pancreatic RNase A (50. $\mu \mathrm{g} / \mathrm{ml}$ in $2 \times \mathrm{SSC}[0.3 \mathrm{M} \mathrm{NaCl}, 0.03 \mathrm{M}$ sodium citrate]) at $37 \mathrm{C}$ for $30 \mathrm{~min}$, or with $\mathrm{S}_{1}$ nuclease as described previously (6) for $60 \mathrm{~min}$ at $45 \mathrm{C}$. In Fig. 6, a $10 \%$ RNase-resistant background was subtracted, and the scale was normalized accordingly; otherwise, only a blank filter background of 15 to 40 counts $/ \mathrm{min}$ was subtracted.

\section{RESULTS}

Kinetics and extent of transcription at high substrate concentration. The kinetics of synthesis of complementary DNA (cDNA) by detergent-disrupted virions of M-MuLV showed a strong dependence on dNTP concentration. With dATP, dCTP, and dTTP each present at $5 \mathrm{mM}$, the rates of $\left[{ }^{3} \mathrm{H}\right] \mathrm{dGMP}$ incorporation were compared in the presence of $0.01,0.2$, and $5 \mathrm{mM}$ dGTP (Fig. 1A). During $2.5 \mathrm{~h}$ of incubation, 8- to 10 -fold more DNA was made at 0.2 $\mathrm{mM}$ than at $0.01 \mathrm{mM}$ dGTP, and 30 -fold more was made at $5 \mathrm{mM}$ than at $0.01 \mathrm{mM}$ dGTP.

The yield of DNA obtained over $24 \mathrm{~h}$ of incubation was also greatly enhanced at high substrate concentrations. With dCTP limiting, incorporation continued for at least $24 \mathrm{~h}$ at a rate determined by the substrate concentration (Fig. 1B). No clear saturation level was reached, even after $24 \mathrm{~h}$ at $5 \mathrm{mM}$ dCTP when the yield of DNA, estimating 70S RNA as 1 to $2 \%$ of the 

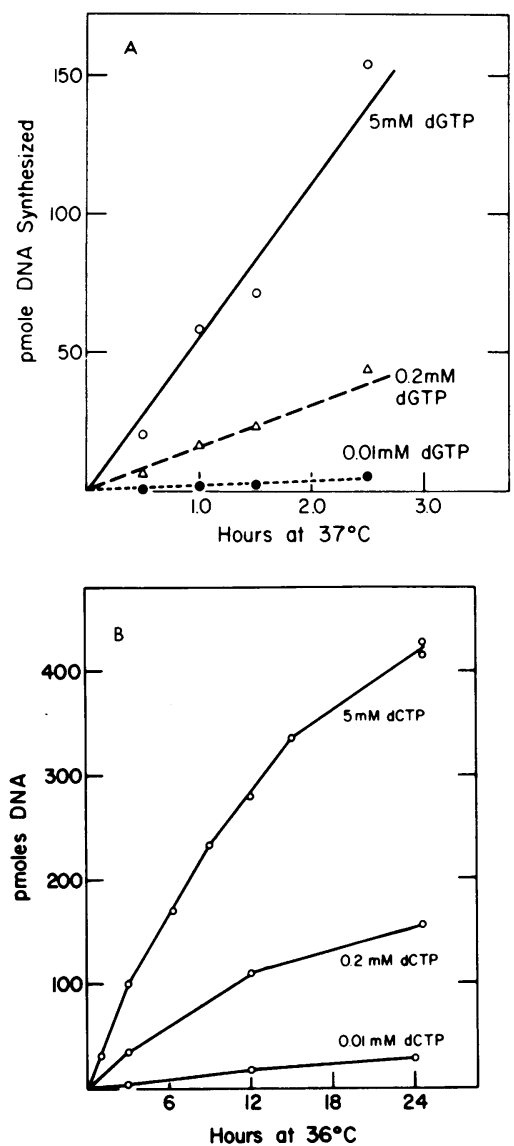

Fig. 1. Effect of substrate concentration on DNA synthesis. (A) Rapid-harvest Moloney virus was incubated at $2.5 \mathrm{mg}$ of protein per $\mathrm{ml}$ in three endogenous reverse-transcriptase reactions. The reaction volumes were $200 \mu \mathrm{l}$ with $5 \mathrm{mM} d G T P$ and $100 \mu \mathrm{l}$ with 0.2 or $0.01 \mathrm{mM}$ dGTP. At the indicated times, 5 - $\mu$ l aliquots were pipetted into $0.5 \mathrm{ml}$ of an ice-cold solution containing $0.1 \mathrm{M}$ sodium $P P_{l}, 20 \mathrm{mM} E D T A$, and $1 \mathrm{mg}$ of yeast tRNA per $\mathrm{ml}$ and kept on ice; $0.5 \mathrm{ml}$ of $25 \%$ trichloroacetic acid was then added to each tube, and the precipitates were collected on Millipore membrane filters. The acid-precipitable radioactivity at zero time was subtracted from the values for each of the incubated samples. Specific activities of the products were 105 counts/min per pmol of DNA, 750 counts/min per pmol of DNA, and 1,160 counts/min per pmol of DNA at 5, 0.2, and $0.01 \mathrm{mM} d G T P$, respectively. (B) Endogenous reactions were performed with $M-M u L V$ at $1 \mathrm{mg} / \mathrm{ml}$ and $\left[{ }^{3} \mathrm{H}\right] d C T P$ limiting. Portions $(20 \mu$ l each) of the reaction mixtures were sealed in siliconized glass capillaries and incubated at $36 C$ for the indicated times. The samples were acid precipitated twice to reduce the background. Acid-precipitable radioactivity in the unincubated samples was between 100 and 300 counts/ min; these values were subtracted from the data shown. The specific activities of the DNA made at 5, 0.2 , and $0.01 \mathrm{mM} d C T P$ were $350,2,800$, and 19,200 virion protein mass, accounted for 35 to $70 \%$ of the input template RNA. In comparison, at 0.2 $\mathrm{mM}$ dCTP the yield was 13 to $25 \%$ of the input, and at $0.01 \mathrm{mM}$ the yield was only 2.5 to $5 \%$.

Effect of substrate concentration on product size. The size of DNA made at various limiting concentrations of dGTP was analyzed by centrifugation of the reverse-transcriptase products through alkaline sucrose gradients (Fig. 2, 3). After $0.5 \mathrm{~h}$ of synthesis at $0.01 \mathrm{mM}$ dGTP, a peak of DNA was evident that sedimented with an approximate size of 200 nucleotides. Higher substrate concentrations allowed synthesis of a class of molecules sedimenting heterogeneously around a peak position of 1,000 nucleotides as well as the molecules sedimenting at 200 nucleotides (Fig. 2). Synthesis of DNA for $2.5 \mathrm{~h}$ generated more 200-nucleotide molecules at $0.01 \mathrm{mM}$ dGTP with, at most, a

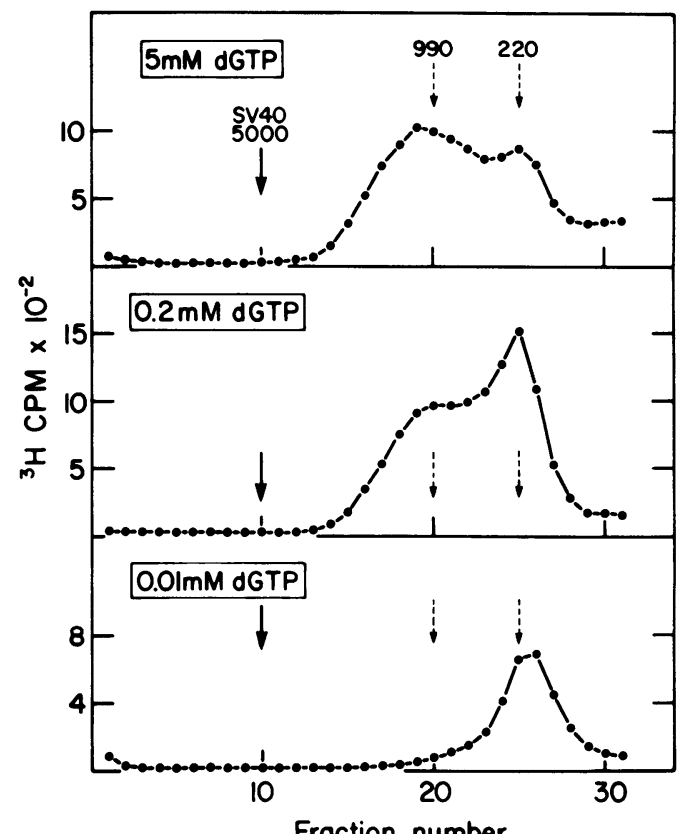

Fig. 2. Reverse-transcriptase products on alkaline sucrose gradients: 0.5 hynthesis. Portions of 100,35 , and $35 \mathrm{\mu l}$ were taken from the reaction mixtures, described in Fig. 1A, containing 5, 0.2, and $0.01 \mathrm{mM}$ $d G T P$, respectively. One-half of the products made at 5 and $0.2 \mathrm{mM} \mathrm{dGTP}$ and all of the product made at $0.01 \mathrm{mM}$ dGTP were analyzed on alkaline sucrose gradients. The direction of sedimentation is from right to left. The dashed arrows mark the calculated positions of DNA 990 and 220 nucleotides long.

counts/min per pmol, respectively. Input RNA, estimated as 1 to $2 \%$ of the mass of virion protein, was 600 to $1,200 \mathrm{pmol}$. 


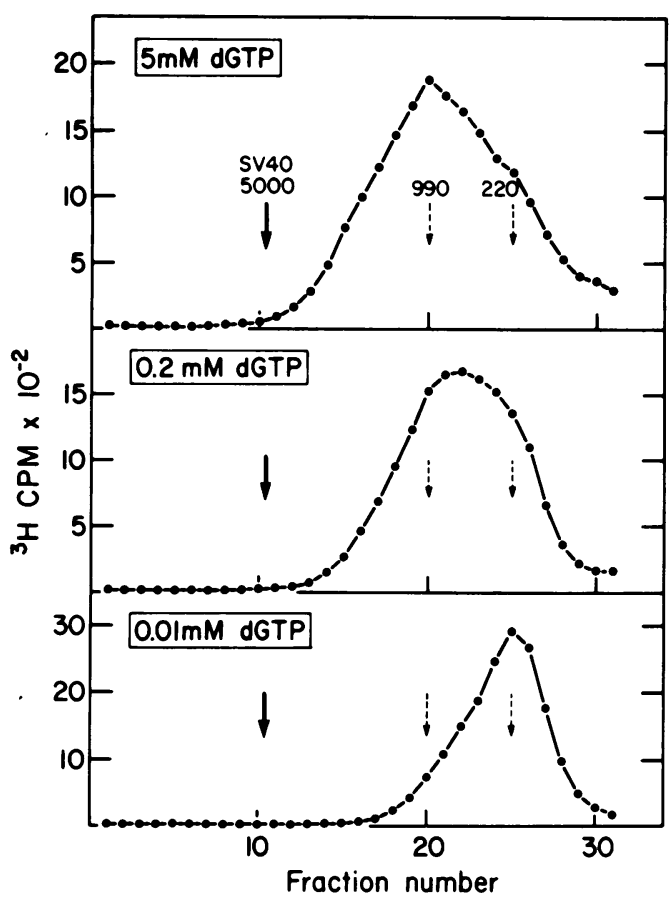

FIG. 3. Reverse-transcriptase products on alkaline sucrose gradients: 2.5 h synthesis. Portions of 50, 20, and $20 \mu l$ were taken from the reaction mixtures, described in Fig. 1A, containing 5, 0.2, and $0.01 \mathrm{mM}$ $d G T P$, respectively. One-sixth of the products made at 5 and $0.2 \mathrm{mM} d G T P$ and all of the product made at $0.01 \mathrm{mM} d G T P$ were analyzed as described in the legend of Fig. 2.

little of the larger DNA. The products from reactions at 0.2 or $5 \mathrm{mM}$ dGTP consisted mainly of the larger class of DNA by $2.5 \mathrm{~h}$ of reaction (Fig. 3).

Maximum size of product DNA. The length of the longest molecules found in these reactions was determined by resedimenting the fastestrunning cDNA in a second alkaline sucrose gradient. The results of one such experiment are shown in Fig. 4. Molecules recovered from the 4,000 - to 7,000-nucleotide region of the first sucrose gradient sedimented in the second gradient with, or slightly behind, the 5,000-nucleotide SV40 linear DNA marker. In other experiments, the maximum product size was 3,000 to 4,000 nucleotides. No definitive evidence for full-length reverse transcripts of about 8,000 or more nucleotides was found.

Hybridization of DNA products to 705 RNA. To investigate whether the long DNA molecules were copied from viral RNA, DNA 900 to 2,000 nucleotides long was recovered from the alkaline gradient shown in Fig. 4A and annealed at $67 \mathrm{C}$ in the presence or absence of an 18-fold excess of unlabeled $70 S$ RNA. Hybrid formation was assayed with $S_{1}$ nuclease. The results (Fig. 5A) show that the DNA was completely ( $>95 \%$ ) protected by the RNA and had no detectable self-complementarity. Thus, the long DNA molecules were copied with fidelity from the $70 S$ RNA.

Sequence complexity and representativeness of cDNA. A reciprocal hybridization experiment was performed to measure the representation of 70S RNA sequences in the cDNA. Products 500 to 2,500 nucleotides long from a 2 -h endogenous reaction were recovered from an alkaline sucrose gradient and annealed to ${ }^{32} \mathrm{P}$ labeled $70 S$ viral RNA at a DNA:RNA ratio of 5 . The protection of the ${ }^{32} \mathrm{P}$-labeled RNA from RNase A is shown in Fig. 5B. The DNA hybridized to more than $80 \%$ of the $70 S$ RNA. The high nuclease resistance in the unhybridized sample was characteristic of the RNA preparation used and did not reflect a rapidly hybridizing component of the DNA.

Given the two general size classes of cDNA made at high substrate concentrations (Fig. 2), it was of interest to compare the larger and smaller components for their total sequence

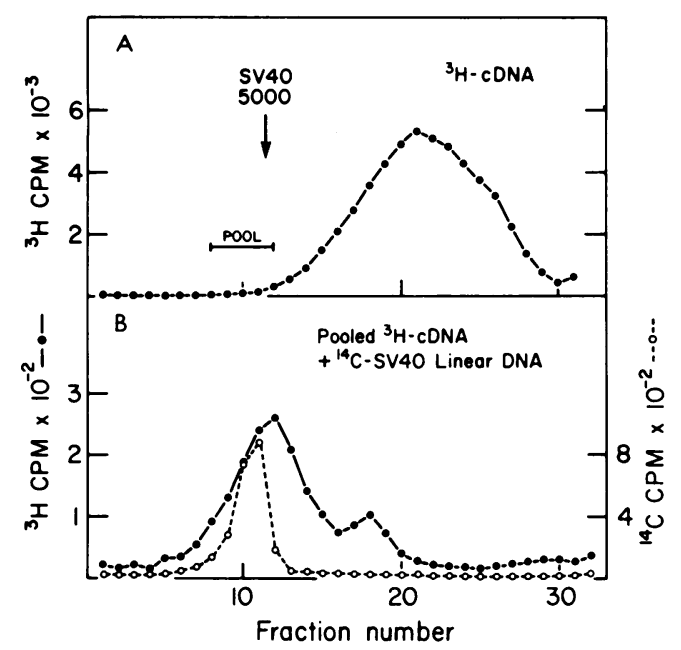

Fig. 4. Size of the largest reverse-transcriptase products. Reverse-transcriptase product labeled with $\left[{ }^{3} \mathrm{H}\right] d G M P$ was prepared from rapid-harvest virus with $d A T P, d C T P$, and $d T T P$, each at $5 \mathrm{mM}$, and with $d G T P$ at $0.4 \mathrm{mM}$. Incubation was for $4 h$. (A) The sedimentation pattern on alkaline sucrose of 0.5 $\mathrm{ml}$ of the product is shown. (B) Those fractions indicated in $(A)$ were pooled from an alkaline sucrose gradient of $2.5 \mathrm{ml}$ of the product. The DNA was ethanol precipitated and analyzed by centrifugation through a second alkaline sucrose gradient. ${ }^{14} \mathrm{C}$ labeled SV40 marker DNA was analyzed in a parallel gradient. 

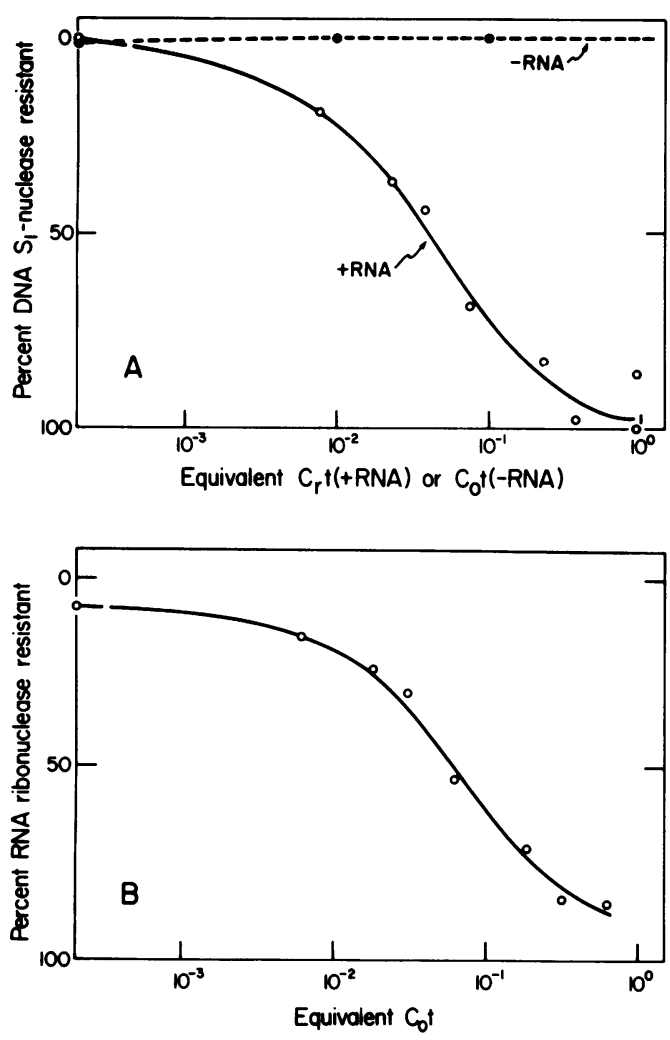

FIG. 5. Hybridization of ${ }^{3} \mathrm{H}$-labeled DNA with 70S RNA. (A) ${ }^{3} \mathrm{H}$-labeled cDNA (specific activity, $6.6 \times$ $10^{5}$ counts/min per $\mu \mathrm{g}$ ) was pooled from fractions 17 through 21 of the preparative gradient described in the legend to Fig. $4 B$. It was annealed, at $0.11 \mu \mathrm{g} / \mathrm{ml}$, with $2 \mu \mathrm{g}$ of unlabeled 70S RNA per ml (+RNA) or self-annealed at $0.22 \mu \mathrm{g} / \mathrm{ml}$ (-RNA) for up to $5 \mathrm{~h}$. The abscissa shows the equivalent $C_{r} t$ values for the reaction with $R N A$ and equivalent $C_{0} t$ values for the self-annealing. Hybrids were assayed with $S_{1}$ nuclease. Input radioactivity was 500 counts $/$ min $(+R N A)$ or 950 counts/min (-RNA) per point. The point plotted on the ordinate represents the value obtained for an unincubated sample. (B) ${ }^{3} \mathrm{H}$-labeled $\mathrm{cDNA}$ (specific activity; $3.2 \times 10^{5}$ counts/min per $\mu \mathrm{g}$ ) from the "large" (2-h) fraction described in the legend to Fig. 6 was hybridized, at $1.6 \mu \mathrm{g} / \mathrm{ml}$, with $0.34 \mu \mathrm{g}$ of ${ }^{32} P$. labeled 70S RNA per $m$ l for up to $5 \mathrm{~h}$. Input ${ }^{32} P$ counts were 2,000 counts/min per point. Hybrids were assayed by RNase resistance. The point on the ordinate shows the value obtained with an unincubated sam. ple.

complexity and for their representativeness, i.e., the relative molarities of different sequences in the DNA population. To prepare DNA, M-MuLV virions were incubated in an endogenous reaction with all dNTP's at $5 \mathrm{mM}$. The products from 0.5 and $2 \mathrm{~h}$ were fractionated on alkaline sucrose gradients, and "large" (500 to 2,500 nucleotides) and "small" (50 to 500 nucleotides) pools were ethanol precipitated. The four DNA fractions were each dissolved at the same concentration and annealed to ${ }^{32} \mathrm{P}$. labeled $70 S$ virion RNA at low DNA:RNA ratios. Ideally, a complete and uniform DNA copy should protect the entire template RNA at a DNA:RNA ratio of 1 . If some sequences were over-represented and others were under-represented in the DNA, higher DNA:RNA ratios would be needed to hybridize the RNA completely. The results (Fig. 6) showed that, after both 0.5 and $2 \mathrm{~h}$ of synthesis, the larger cDNA was highly respresentative, whereas the smaller cDNA was much less uniform. At a DNA:RNA ratio of 1 , as well as at a ratio of 10 , large DNA from 0.5 or $2 \mathrm{~h}$ of synthesis protected approximately $70 \%$ of the ${ }^{32} \mathrm{P}$-labeled RNA. In contrast, smaller cDNA from $0.5 \mathrm{~h}$ of synthesis protected only about $30 \%$ of the ${ }^{32} \mathrm{P}$-labeled RNA at a

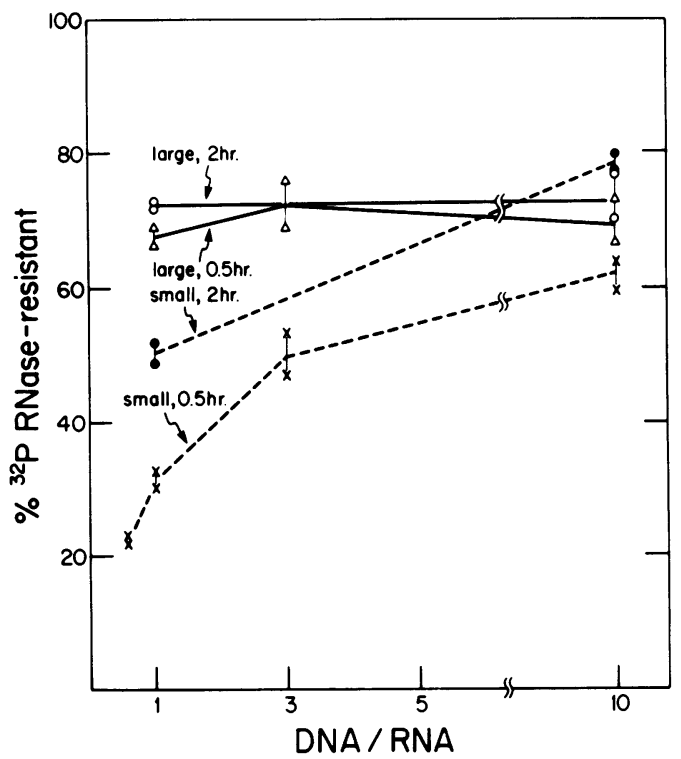

Fig. 6. Protection of ${ }^{32} P$-labeled 70S RNA by ${ }^{8} \mathrm{H}$ labeled cDNA at different DNA:RNA ratios. Reversetranscriptase product labeled with $\left[{ }^{3} H\right] d C M P$ was prepared in a reaction mixture with all dNTP's at 5 $m M$. A portion was taken after $0.5 h$ of synthesis, and another portion was incubated for $2 \mathrm{~h}$. The products were fractionated on alkaline sucrose gradients into "large" and "small" pools as described in the text. Four hybridization mixtures were prepared, each containing "2P-labeled RNA, 0.2\% SDS, 0.9 M LiCl, and $1.3 \mu \mathrm{g}$ of the ${ }^{3} \mathrm{H}$-labeled DNA sample per $\mathrm{ml}$.

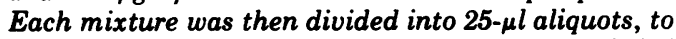
each of which was added $3 \mu l$ of buffer or unlabeled $70 S$ RNA. Incubation was for $8 h$ at $67 \mathrm{C}$, to an equivalent $C_{0} t$ of 0.7 . For each reaction, the zero-time $R N a s e$ resistance and input radioactivity before and after incubation were determined. Values shown have been corrected for the RNase-resistant background. 
DNA:RNA ratio of 1 , although at higher ratios it hybridized to over $60 \%$ of the RNA. A similar sensitivity to the DNA:RNA ratio was found when ${ }^{32} \mathrm{P}$-labeled RNA was protected with the small products of the 2-h reaction, although a greater percentage of the RNA was annealed at a DNA:RNA ratio of 1 .

The maximum percentage of ${ }^{32} \mathrm{P}$-labeled RNA that could be hybridized at a vast DNA excess was not determined for the conditions of this experiment. Therefore, it is possible that the 70 to $75 \%$ saturation level underestimates the complexity of the DNA.

In related experiments (unpublished data) ${ }^{3} \mathrm{H}$-labeled DNA 650 to 3,000 nucleotides long from a similar 2-h endogenous reaction was hybridized with unlabeled $70 S$ RNA at low RNA:DNA ratios. Any sequence present in more copies in the DNA than in the RNA should remain unhybridized under these conditions. In this case, at a calculated RNA:DNA ratio of 1 , 80 to $90 \%$ of the cDNA was protected from $S_{1}$ nuclease, suggesting again that, at most, a very small percentage of this DNA could consist of many copies of a single RNA sequence.

Thus, according to both of these experiments, most of the larger DNA molecules (weightaverage size, ca. 1,000 nucleotides) must come from different parts of the RNA template. The over-representation of a few sequences, which would be characteristic of molecules predominantly starting at one point, was found only in the small products of the high-substrate reactions.

\section{DISCUSSION}

There appears to be no limit to the size of DNA molecules that can be made by reverse transcriptase. We have shown here that, by maintaining a high dNTP concentration, the enzyme in the virion can make molecules 5,000 nucleotides long. The pure enzyme, using oligo(dT)-primed, poly(A)-containing RNAs as template, can completely copy globin mRNA of 650 nucleotides $(5,10)$ and even poliovirus RNA 7,500 nucleotides long (S. Drost and D. Baltimore, unpublished data).

Using high levels of dNTP, we have shown that two size classes of the reverse-transcriptase product can be made by virions of M-MuLV. The smaller-size class is relatively homogenous; on polyacrylamide gels it has been shown to consist primarily of one species with a very discrete size (Haseltine, Rothenberg, and $\mathrm{Bal}$ timore, unpublished data). The smaller molecules also have a limited complexity based on their inability to protect more than $30 \%$ of the viral RNA at a 1:1 DNA:RNA ratio. Their abiliity to protect viral RNA at all is probably a measure of the contamination of the small, discrete molecules with small heterogeneous DNAs. The larger-product class is much more heterogeneous in size and has a complexity at least $70 \%$ that of viral RNA (Fig. 6). Its size averages about 1,000 nucleotides, and it therefore appears to represent molecules coming from separate initiation events at different sites on the RNA template. It is not a result of random degradation of even longer molecules because added SV40 DNA was not degraded in the reaction mixture. Why it does not represent a copy of the whole RNA $(7,500$ to 10,000 nucleotides) is not known.

The use of high dNTP concentrations affects mainly the synthesis of the large heterogeneous DNA molecules, which are not made otherwise. Synthesis of the smaller products is also stimulated by increasing the dNTP concentration but to a less significant extent. The ability of high dNTP concentrations to support synthesis of the large class of DNA molecules could be due to a stimulation of the initiation of their synthesis and/or to a stimulation of their elongation. An effect on elongation would be observed if special regions of structure in the template require high $\mathrm{dNTP}$ concentrations to allow the enzyme to copy them rather than to fall off of the template.

The ability to make long, representative DNA transcripts in the endogenous reaction has an immediate practical consequence. These molecules should be excellent probes for molecular hybridization. Their size allows them to anneal at the same rate as sheared cellular DNA and ensures that they will not be displaced from hybrids as are probes smaller than the competing unlabeled DNA (2). Their high representativeness means that the proportion of probe hybridized can be interpreted simply as the proportion of viral sequences represented. Because of the high dNTP concentrations required to make these molecules, however, it is prohibitive to use high-specific activity precursors. Therefore, the DNA will have to be postlabeled to use it as a probe, possibly by radioiodination (4).

\section{ACKNOWLEDGMENTS}

This work was supported by a contract from the Virus Cancer Program of the National Cancer Institute and by Public Health Service grant CA 14051 from the National Cancer Institute. E. R. is a predoctoral fellow of the National Science Foundation. D. B. is an American Cancer Society Research Professor.

\section{LITERATURE CITED}

1. Baltimore, D. 1970. RNA-dependent DNA polymerase in virions of RNA tumor viruses. Nature (London) 226:1209-1211. 
2. Beckmann, J. S., and V. Daniel. 1974. Relative stabilities of RNA/DNA hybrids: effect of RNA chain length in competitive hybridization. J. Mol. Biol. 89:355-362.

3. Britten, R. J., and J. Smith. 1970. A bovine genome. Carnegie Inst. Washington Yearb. 68:378-386.

4. Commerford, S. L. 1971. Iodination of nucleic acids in vitro. Biochemistry 10:1993-1999.

5. Efstratiadis, A., T. Maniatis, F. C. Kafatos, A. Jeffrey, and J. N. Vournakis. 1975. Full length and discrete partial reverse transcripts of globin and chorion mRNA's. Cell 4:367-378.

6. Fan, H., and D. Baltimore. 1973. RNA metabolism of murine leukemia virus: detection of virus-specific RNA sequences in infected and uninfected cells and identification of virus-specific messenger RNA. J. Mol. Biol. 80:93-117.

7. Fan, H., and M. Paskind. 1974. Measurement of the complexity of cloned Moloney murine leukemia virus 60 to $70 S$ RNA: evidence for a haploid genome. J. Virol. 14:421-429.

8. Faras, A. J., J. M. Taylor, J. P. McDonnell, W. E. Levinson, and J. M. Bishop. 1972. Purification and characterization of the deoxyribonucleic acid polymerase associated with Rous sarcoma virus. Biochemistry 11:2334-2342.
9. Garapin, A. C., L. Fanshier, J. Leong, J. Jackson, W. Levinson, and J. M. Bishop. 1971. Deoxyribonucleic acid polymerases of Rous sarcoma virus: kinetics of deoxyribonucleic acid synthesis and specificity of the products. J. Virol. 7:227-232.

10. Imaizumi, T., H. Diggelmann, and K. Scherrer. 1973. Demonstration of globin messenger sequences in giant nuclear precursors of messenger RNA of avian erythroblasts. Proc. Natl. Acad. Sci. U.S.A. 70:1122-1126.

11. Leis, J. P., and J. Hurwitz. 1972. Isolation and characterization of a protein that stimulates DNA synthesis from avian myeloblastosis virus. Proc. Natl. Acad. Sci. U.S.A. 69:2331-2335.

12. Morrow, J. F., and P. Berg. 1972. Cleavage of simian virus 40 DNA at a unique site by a bacterial restriction enzyme. Proc. Natl. Acad. Sci. U.S.A. 69:3365-3369.

13. Studier, W. 1965. Sedimentation studies of the size and shape of DNA. J. Mol. Biol. 11:373-390.

14. Temin, H., and D. Baltimore. 1972. RNA-directed DNA synthesis and RNA tumor viruses, p. 129-186. In K. M. Smith and M. A. Lauffer (ed.), Advances in virus research, vol. 17. Academic Press Inc., New York.

15. Temin, H., and S. Mizutani. 1970. RNA-dependent DNA polymerase in virions of Rous sarcoma virus. Nature (London) 226:1211-1213. 